\title{
An Investigation into Communication Climate and Staff Efficiency in South-Western Nigeria Tertiary Institutions
}

\author{
Ijaduola, 'Kayode Olu.
}

\begin{abstract}
This study examined the relationship between communication climate and staff efficiency in selected tertiary institutions in south-western Nigeria. Using the stratified random sampling technique, 1500 workers were drawn from public and private tertiary institutions i.e Universities, Polytechnics and Colleges of Education). The descriptive survey research design was adopted while data were collected via questionnaire tagged Communication Climate and Staff Efficiency Questionnaire (CCSEQ). This questionnaire was also complemented with an interview schedule. Five null hypotheses were generated while the Pearson's product moment correlation and t-test statistics were employed in testing the hypotheses at 0.05 error margins. Plausible recommendations were posited as a result of the findings.
\end{abstract}

Keywords: Communication Climate, Staff, Staff Efficiency, Tertiary Institutions, Organization.

\section{Introduction}

Every organization has a certain implicit and explicit goals and objectives. For any organization to achieve its goals and objectives, Ubeku (2003), Plaxton (2005) and Familola (2007) opined that there has to be a set of activities, functions and interactions among the members of the organization. Correspondingly, the various activities and social interactions or climate that will result in group goal achievement depend on a system of communication among the group. 
However, through communication process, the roles, activities and interactions are identified, allocated, effectuated and evaluated. Therefore, effective communication lies at the very foundation of all social organizations. Invariably, each set of individuals has a specific style or process of communication. To the extent to which the group communicates effectively, to that extent would the group be functional or dysfunctional (Nwakwo, 1977; Garrett, 2001; Andrews, 2004; and Odewale, 2005). As Omotoye (2007) puts it, the success of an organization depends on efficiency and effectiveness. It is the holy marriage between the two concepts that can help an organization. It is the mode of communication arising out of institutional direction that begets staff efficiency or inefficiency, effectiveness or ineffectiveness.

Communication is intended for conveying information, instruction, advice, feelings, opinions and facts correctly and accurately from one person to another (Alo, 2002, Ibeh, 2003: Chubin, 2003: Baxter, 2005; Sanni, 2005; Olaleye, 2006). According to Ijaduola, (2001, 2006a), good communication helps to stimulate enthusiasms raise the interest and motivation of those to whom it is directed. Similarly, communication is the means by which people are linked together in an organization to achieve a common purpose (Nwachukwu, 2000; Mclarney, 2002 and Trochim, 2002). As opined by Grooves (2003), Hauser (2005) and Demuren (2006), communication is the process by which people attempt to share meaning via the transmission of symbolic messages. It is the means by which people are linked together in an organization to achieve a common purpose. To this end, Fasakin (2002), Ijaduola (2004) and Alao (2005) submitted that communication involves two persons i.e the sender and the receiver; communication does not take place unless the receiver interprets exactly the information being transmitted. It is what the receiver understands not what the sender says. 
It is believed according to Ayepekun, (2004); Wickesberg, (2004); Ijaduola (2007a) that communication climate occupies a vital part of managerial function; and unless we communicate with each other, we cannot plan, organize, control, lead or execute. Communication climate has been described by Oso (2002) as the link that holds any organization together. Observing the contemporary communication climate in tertiary institutions in Nigeria, Ijaduola (2006b) submitted that the system has been witnessing notable changes in terms of managers' and administrators system of communication with their workers. These changes have had series of effects on workers' efficiency in tertiary institutions in Nigeria.

Basically, the tertiary institutions workers comprised the teaching and non-teaching staff. As opined by Whedouri (2000), the workers perform different but important roles, which call for effective interdisciplinary communication regarding assessment, intervention, outcomes, and the students' moral and academic up-bringing. As opined by Ijaduola (2007b), much of the job done in tertiary institutions was conversational in nature, which required good interpersonal relationship between the workers and the various tertiary institutions communities as well as with other co-workers and the society at large.

However, people understand and interpret messages differently. In communication, noise, or unwanted interference can distort a message. Noise is always a potential threat to effective communication because it can interfere with the accuracy of a massage. Noise creates a barrier for effective transmission and receiving of message (Mayers; 2003; Olarinde, 2005; Ijaduola, 2007c).

It is not surprising as noted by Helsel (2000) that some managers do not communicate well, and do not set an organizational climate where communication within the organization is managed effectively. This development according to Stoner (2003) is not unconnected with the fact that leadership is closely linked with communication because the 
type or process of communication determines the type and process of leadership. Onifade (2001) proffered that poor communication was self-sustaining because it eliminates an important "feedback too". Staff is loathing to "communicating their concerns about communication because they do not perceive the manager as receptive. Consequently effective organizational communication regardless of forms requires three things (Omolaja, 2001; Popoola, 2004; Rubin, 2005; Ward and Hausen, 2006; Ijaduola, 2007d).

Firstly, all players must have the appropriate skills and understanding to communicate well. Communication is not a simple process, and many people simply do not have the required depth of understanding of communication issues.

Secondly, effective organizational communication requires a climate or culture that supports effective communication. More specifically, this climate involves trust, openness, reinforcement of good communication practices, and shared responsibility for making communication effective.

Thirdly, effective communication climate does not just happen. It develops as a result of an intentional effort on the part of the management and staff. If managers want to improve communication, they will need to ensure they and their staff have the skills and knowledge necessary to communicate effectively. This may mean formal training is in order, or it may mean that they coach staff and provide feedback so that they can improve. This is because members of staff desire to know what to expect as well as what is expected of them.

\section{Hypotheses}

The following five null hypotheses were posited and tested at 0.05 level of significance: 
1. There is no significant relationship between communication climate and staff efficiency in southwestern Nigeria tertiary institutions.

2. There is no significant difference between communication climate and efficiency of male and female staff.

3. There is no significant difference between communication climate and efficiency of teaching and non-teaching staff.

4. There is no significant difference between communication climate and efficiency of private and public tertiary institutions staff.

5. There is no significant difference between communication climate and efficiency of young and old staff.

\section{Methodology}

The study adopted the descriptive survey research design, the sample comprised 1,500 workers stratifiedly selected from public and private tertiary institutions in the south-western Nigeria. The careful selection consisted of 750 males, females, teaching, non-teaching, young (i.e below 40 years), old (i.e 40 years and above), private and public tertiary institutions workers respectively. The instrument used for data collection was adapted from Dickie (1999). The instrument was adjusted and validated by other research experts before it was tested for reliability value. The Kudder Richardson's correlation KK2 formular was used and a reliability value of $r=0.94$ was obtained. However the instrument has been used successfully in similar studies by Komolafe (2001) and Benjamin (2004). The questionnaire were personally administered to the respondents; hence a full return rate. The five hypotheses developed were tested using the pearson's product moment correlation and t-test statistical tools at 0.05 level of significance.

\section{Data Analysis}

$\mathrm{H}_{0} 1$ : There is no significant relationship between communication climate and staff efficiency in south-western Nigeria tertiary institutions. 
Table one indicated that there was a significant relationship between communication climate and staff efficiency because the $\mathrm{r}$ calculated $=$ 0.649 at 0.05 level of significance. This implies that effective communication climate is an indispensable determinant of staff efficiency in tertiary institutions. Hence, the null hypothesis ealier posited was rejected.

$\mathrm{H}_{0}$ 2: There is no significant difference between communication climate and efficiency of male and female staff.

As shown in table 2, the obtained value of $t(0.313)$ is less than critical value of 1.96 at 1498 degrees of freedom and 0.05 level of significance. This result portrays that irrespective of gender, good communication climate is of paramount importance to staff efficiency. Therefore, the null hypothesis which states that there is no significant difference between communication climate and efficiency of male and female staff in south-western Nigeria tertiary institutions is accepted.

$\mathrm{H}_{0} 3$ : There is no significant difference between communication climate and efficiency of teaching and non teaching staff.

Table 3 showed a t-value of 1.01 which is less than t-table (1.96) at 1498 degrees of freedom and 0.05 level of significance. Consequently, there is no significant difference between communication climate and efficiency of teaching and non-teaching staff.

$\mathrm{H}_{0} 4$ : There is no significant difference between communication climate and efficiency of private and public tertiary institutions staff.

Again, as indicated in table 4, the calculated value of $t(0.224)$ is less than t-table (1.96) at 1498 degrees of freedom and 0.05 level of significance. As a result, the null hypothesis is upheld. 
Ijaduola, 'Kayode Olu.

$\mathrm{H}_{0}$ 5: There is no significant difference between communication climate and efficiency of young and old staff.

Finally, data analysis as shown in table 5 portrayed that the calculated $\mathrm{t}$ (1.23) is less than the table value of 1.96 at 1498 degrees of freedom and 0.05 level of significance. Based on this, the null hypothesis was accepted.

\section{Discussion of findings}

The findings of hypothesis one as indicated in table one showed that there was a significant relationship between communication climate and staff efficiency in south-western Nigeria tertiary institutions. This finding was a strong reflection between organizational structure and staff level of efficiency. In support of the finding, Ijaduola (2001, 2006a) had argued that good communication goes a long way to stimulate enthusiasm, raise the motivation of those to whom they are directed. This finding also aligns with the opinions of Ubeku (2003), Plaxton (2005) and Familola (2007) that there has to be a set of activities, functions and interactions among the member of the organization. To this end, the various activities and social interactions or climate that will result in group goal achievement depend on a system of communication among the group. The finding is also congruous with the contentions of Nwakwo, (1977), Garrett (2001), Andrews (2004) and Odewale (2005) that effective communication lies at the very foundation of all social organizations. They believe that the extent to which the group communicates effectively, to that extent would the group be functional or dysfunctional.

It was also established by the study that there were no significant differences between communication climate and efficiency of male and female staff; teaching and non-teaching staff; private and public tertiary institutions staff; young and old staff. This finding agrees with the submissions of Alao (2002), Ibeh (2003), Chubin (2003), Baxter (2005) Sanni (2005) and Olaleye (2002) who posited that effective communication is intended for conveying information, instruction, advice, feelings, opinions and facts correctly and 
accurately from one person to another irrespective of gender, age, type of institution and other personality characteristics.

However, it could be argued further that if the initiative of an individual member of an organization is to be retained in appropriate degree, it is the role of the communication process adopted to provide enough knowledge to enable the coordination of his actions with those of others effectively. He needs information and this comes from intensive communication between the team members prior to embarking on a course of action at all. It is universally believed that one of the major functions of the executive is decision-making, and there is the widespread view among executives of all kinds of organizations that group thinking can be a desirable alternative to individual analysis. The idea here is that the administrator should always encourage decisional participation of his members of staff. Such participation relies mainly on a give-and-take process of communication.

\section{Recommendations}

Based on the findings of this study that effective communication climate is indispensable to staff efficiency in Nigeria tertiary institutions, the following recommendations are proffered:

First and foremost, a manager can improve his chance of success in an organizational communication effort by carefully diagnosing the organizations. This would include analyzing the importance of the problems, the people most likely to resist efficiency and effectiveness, the workers who have the relevant information which will enhance efficiency and the speed with which the problems need to be addressed.

Nonetheless, any organization that is result oriented should improve upon the working condition of workers, in terms of provision of appropriate incentives. Management should see to continuous review of management and workers' education curriculum and instruction. 
Ijaduola, 'Kayode Olu.

The changing nature of organizational problems in Nigeria demands continuous review of curriculum education and training on management. This will help to improve workers' performance in order to meet up with challenges.

Furthermore, organization should continuously provide training to workers to improve their skills and expertise to enable them to know better, to learn new methods of performance and to improve handling of equipment used in the production process.

Finally, workers involvement in planning and implementation in organization should be encouraged. This is because workers have ideas, which can be useful, and they tend to accept decision better if they participate in them. Besides, they may work more intelligently and harder if through participation in decision making they are better informed about reasons for and the intention of the decision making process will lead to strengthening of team work, improve productivity or service quality, improve workers' morale and gear them to managerial efficiency. 


\section{References}

Alao, J.M. (2005). Administrators' information capacity and students' performance in the Nigeria Polytechnics. Unpublished Ph.D Thesis, University of Calabar.

Alo, O.O. (2002). Gender differences in persuasive communication and attribution of success and failure. Ph.D Thesis, University of Lagos.

Andrews, B.T. (2004). Management and moral. Cambridge Mass: Harvard University Press.

Ayepekun, A.O. (2004). How to organize information system. Business Renew, 46 (3) 8-19.

Baxter, L.A. (2005). The affinity - seeking function of communication. Communication Monograph, 62, 80-85

Benjamin, O. (2004). Effects of principals' communication styles on staff task performance in Osun State secondary schools. Unpublished M.Ed dissertation, University of Ibadan.

Chubin, D.W. (2003). Interaction involvement: A cognitive dimension of communicative competence. Quarterly Journal of Speech, 61,78-90.

Demuren, A.K. (2006). Fundamentals of Educational Administration. IjebuIgbo: Samuel Publishers.

Familola, J. (2007). Managerial psychology. Ibadan: Felix Enterprises.

Fasakin, O.K. (2002). A comparison of persuasive strategies used by female and male school administrators in selected secondary school in Ondo State. M.Ed Dissertations, University of Lagos.

Dickie, F.R. (1999). Effective communication as a factor influencing workers' efficiency in tertiary institution. CSA Bulletin. 9, 21-35.

Garrett, R.J. (2001). An approach to the measurement of psychological characteristic of college environments. Journal of Educational Psychology, 8 (2) 48-59.

Grooves, R.M. (2003). The effects of non-verbal communication and gender on impression formation in opening statements. Southern Communication Journal, 61, 221-236.

Hauser, Q.M. (2005). Management in Education; Principles and Practice. London: DP Publications.

Helsel, N.R. (2000). School organizational climate some validity studies. Canadian Education and Research Digest 9, 429-438.

Ibeh, R. (2003). Group communication and problem solving effectiveness in selected secondary schools in Abia State. M.Ed Dissertation, University of Benin. 
Ijaduola, K.O. (2001). Reflections on school organization and management. Lagos: Fortunate Books Publishers.

Ijaduola, K.O. (2004). Effects of staff perception of participative administration on staff efficiency in Nigerian Secondary Schools. African Research Development, Vol. 4 (3) pp 21-33.

Ijaduola, K.O. (2006a). Principals information management as a correlate of academic achievement in secondary schools. Journal of Educational Management. Vol, 2 No1.pp. 172-187.

Ijaduola, K.O. (2006b). Application of e-human resources in University administration: An explanatory investigation. Sokoto Educational Review. Vol. 8. No2. Pp. 251-263.

Ijaduola, K.O. (2007a). An evaluation of public relations awareness of managers of secondary schools. EDUCERE: Journal of Educational Research. Vol. 4, pp, 111-121.

Ijaduola, K.O. (2007b). The impact of information and Communication Technology (ICT) on school administration. THE SIGNAL: Journal of Development Issues and Policy in Africa (accepted).

Ijaduola, K.O. (2007c). A survey of teacher-students relations in secondary schools. African Research Review. Vol. 1 No 3. Pp.67-76.

Ijaduola, K.O. (2007d). Decision-making strategies for effective crisis management among Nigeria school principals. Journal of Educational Management. Vol. 6. No.3 pp. 102-113.

Komolafe, B.A (2001). Effective communication and the school administrator. Unpublished B.Ed. project. University of Lagos.

Mclarney, W.J. (2002). Management training cases and principles Ontario: Richard D Unwin Inc.

Mayers, M.L (2003). Information system: trends and issues. London: Allen and Unwin.

Nwachukwu, C.C. (2000). Management theory and practice. Ibadan: Fep Publishers Ltd.

Nwakwo, J.I. (1977). Perception of the administrative roles of the principal and the school climate as factors in students' conflict behavior. Unpublished Ph.D Thesis, University of Ibadan.

Odewale, O.O (2005). Personnel management: An introduction. Abeokuta: Etherkay Publications.

Olaleye, O.O (2006). Styles in Communication Mimeograph. Faculty of Education, University of Ilorin.

Olarinde, O.O. (2005). Productivity and efficiency in education. Journal of educational Research. 21 (2) 211-224. 
Omolaja, M.A. (2001). Human resources management and industrial relations functions in modern organization. In J.O. Obikoya and others (Eds). Human resource management and industrial relations in Nigeria, Ago-Iwoye, CESAP, OOU, pp. 24-50.

Omotoye, A.B. (2007). A new look at management communication. Lagos: Lovefed Book.

Onifade, O.O. (2001). Management: office, business education.

Oso, L. (2002). Communication and Learning. Abeokuta: Goad Publishers.

Plaxton, M.K. (2005). Foundation of school Administration. London: Oxford University Press.

Popoola, R.A (2004). Organizational communication evaluation; An overview. In R.A. Odesola (Ed). Handbook of organizational communication. Oyo: Ablexi Books, pp. 275-318.

Rubin, J.W. (2005). Communication research methods. Glenview. IL: Scot Foresman.

Sanni, O.R (2005). Information technology and the administration of schools. unpublished B.Ed project. Delta State University.

Stone, R.C. (2003). The idea of managing a University. News front Digest, 33.

(http://www.unimelb.edu.an/ExtRels/un/archive/2003/418/opionionpi ece.html/

Trochim, W.M.K. (2002). Research method knowledge base. Retrieved on 20/4/2006 from http://www.socialresearchmethod.net/kb/quasiexp.htm.

Ubeku, D.L. (2003). The effect of socio-economic setting and organizational climate on workers efficiency. African Journal of Educational Research 4 (4) 19-31.

Ward, M.R. and Hansen, B. (2006). The relationship between perceived job characteristics and satisfaction among occupational status groups. Journal of Sociology of Work and Occupations. Vol .8 (4) pp.119-131. 
Table 1: Pearson's product movement correlation of the relationship between communication climate and staff efficiency in south-western Nigeria tertiary institutions.

\begin{tabular}{|l|l|l|l|}
\hline Pearson $(\mathrm{r})$ & $\mathrm{N}$ & Sig 2 tailed & Remark \\
\hline 0.649 & 1500 & $0.000 \mathrm{P}<0.05$ & Significant \\
\hline
\end{tabular}

Table 2: T-test analysis of the difference between communication climate and efficiency of male and female staff

\begin{tabular}{|l|l|l|l|l|l|l|l|}
\hline Group & $\mathrm{N}$ & $\mathrm{X}$ & $\mathrm{SD}$ & $\mathrm{DF}$ & $\mathrm{T}$-cal & $\begin{array}{l}\text { T- } \\
\text { table }\end{array}$ & Remark \\
\hline $\begin{array}{l}\text { Male } \\
\text { staff }\end{array}$ & 750 & 24.14 & 5.05 & 1498 & 0.0313 & 1.96 & Ns \\
\hline $\begin{array}{l}\text { Female } \\
\text { staff }\end{array}$ & 750 & 19.92 & 3.88 & & & & \\
\hline
\end{tabular}

Table 3: T-test analysis of the difference between communication climate and efficiency of teaching and non-teaching staff

\begin{tabular}{|l|l|l|l|l|l|l|l|}
\hline Group & $\mathrm{N}$ & $\mathrm{X}$ & $\mathrm{SD}$ & $\mathrm{DF}$ & $\mathrm{T}$-cal & $\begin{array}{l}\mathrm{T} \text { - } \\
\text { table }\end{array}$ & Remark \\
\hline $\begin{array}{l}\text { Teaching } \\
\text { staff }\end{array}$ & 750 & 36.61 & 6.03 & 1498 & 1.01 & 1.96 & Ns \\
\hline $\begin{array}{l}\text { Non- } \\
\text { teaching } \\
\text { staff }\end{array}$ & 750 & 40.03 & 8.14 & & & & \\
\hline
\end{tabular}


An Investigation into Communication Climate and Staff Efficiency...

Table 4: T-test analysis of the difference between communication climate and efficiency of private and public tertiary institutions staff

\begin{tabular}{|l|l|l|l|l|l|l|l|}
\hline Group & N & X & SD & DF & T-cal & $\begin{array}{l}\text { T- } \\
\text { table }\end{array}$ & Remark \\
\hline $\begin{array}{l}\text { Private } \\
\text { institutions }\end{array}$ & 750 & 31.44 & 7.42 & 1498 & 0.224 & 1.96 & Ns \\
\cline { 1 - 4 } $\begin{array}{l}\text { Public } \\
\text { institutions }\end{array}$ & 750 & 34.01 & 6.71 & & & & \\
\hline
\end{tabular}

Table 5: T-test analysis of the difference between communication climate and efficiency of young staff and old staff

\begin{tabular}{|l|l|l|l|l|l|l|l|}
\hline Group & $\mathrm{N}$ & $\mathrm{X}$ & $\mathrm{SD}$ & $\mathrm{DF}$ & $\mathrm{T}$-cal & $\begin{array}{l}\mathrm{T}- \\
\text { table }\end{array}$ & Remark \\
\hline $\begin{array}{l}\text { Young } \\
\text { staff }\end{array}$ & 750 & 23.60 & 4.79 & 1498 & 1.23 & 1.96 & Ns \\
\hline $\begin{array}{l}\text { Old } \\
\text { staff }\end{array}$ & 750 & 20.82 & 3.05 & & & & \\
\hline
\end{tabular}

